\title{
Morphometric Discriminant Analysis of isolated chondrichthyan scales for palaeoecological inferences: the Middle Triassic of the Iberian Chain (Spain) as a case of study
}

\author{
H. Ferrón' ${ }^{1}$, C. Pla ${ }^{1}$, C. Martínez-Pérez ${ }^{1,2}$, M.J. Escudero-Mozo3, ${ }^{3,4}$ H. Botella ${ }^{1 *}$ \\ ${ }^{1}$ Departamento de Geología, Universidad de Valencia, Avda. Dr. Moliner, 50, 46100 Burjassot, Spain. \\ ${ }^{2}$ School of Earth Sciences, University of Bristol, Wills Memorial Building, Queen's Road, Bristol BS8 1RJ, United Kingdom. \\ ${ }^{3}$ Departamento de Estratigrafía, Universidad Complutense de Madrid, C/José Antonio Novais 12, 28040 Madrid, Spain \\ ${ }^{4}$ Instituto de Geociencias IGEO (CSIC,UCM), C/José Antonio Novais 12, 28040 Madrid, Spain \\ e-mail addresses: humfeji@alumni.uv.es (H.F.),M.Cristina.Pla@uv.es (C.P.),Carlos.Martinez-Perez@bristol.ac.uk (C.M.-P.); mjescudero@geo.ucm.es (M.J.E.-M.) \\ Hector:Botella@uv.es (H.B., *corresponding author)
}

Received: 12 December 2012 / Accepted: 4 December 2013 / Available online: 25 February 2014

\begin{abstract}
Palaeontological studies on exosqueletal disarticulated remains of chondrichthyans have focused on teeth and only less interest has been paid to scales due their limited taxonomic and systematic significance. However, classical works linking the morphology and the function of the squamation in extant sharks suggest that, despite their limited taxonomic value, the study of isolated scales can be a useful tool for palaeoenvironmental and palaeoecological inferences. Following this idea, we have analyzed the fossil record of shark scales from two Middle Triassic sections of the Iberian Chain (Spain), identifying different functional types by means of a morphometric discriminant analysis. From a total of 1136 isolated chondrichthyan scales, 25\% were identified as abrasion resistant scales, $62 \%$ as drag reduction scales and $13 \%$ as scales of generalized functions. The elevated proportion of abrasion resistant scales suggests that this chondrichthyan palaeocommunity was highly dominated by benthic sharks that lived over a hard sea floor. However, one of the stratigraphical levels studied (He-20), presents statistically significant differences from the others, showing a lower percentage of abrasion resistant scales and a larger percentage of drag reduction scales. This level can be linked with storm episodes that could introduce remains of bentho-pelagic or pelagic forms in the inner platform.. Finally, partial correlation analysis between relative abundances of functional scale types and tooth-based taxa from the same sections provide positive correlation between teeth of Hybodus and Pseudodalatias and drag reduction scales, and teeth of Prolatodon and abrasion strength scales.
\end{abstract}

Keywords: Triassic, Chondrichthyes, scales, teeth, Iberian Chain

Resumen

Los estudios paleontológicos de restos desarticulados de condrictios se han centrado en los dientes, no prestando prácticamente interés al estudio de sus escamas debido a su limitada importancia taxonómica y sistemática. Sin embargo, algunos trabajos clásicos que han relacionado su morfología y función en base al estudio de la escamación de tiburones actuales, sugieren que, a pesar de su limitado valor taxonómico, el estudio de las escamas aisladas puede ser una herramienta útil para obtener inferencias paleoambientales y paleoecológicas. Siguiendo estas ideas, se ha analizado el registro fósil de escamas de tiburón de dos secciones del Triásico Medio de la Cordillera Ibérica (España), identificando diferentes tipos funcionales por medio de un análisis morfométrico discriminante. De un total de 1.136 escamas aisladas de condrictios, el $25 \%$ de ellas fueron identificadas como escamas resistentes a la abrasión, el $62 \%$ como de reducción de la fricción con el agua y el 13\% de las escamas como de función generalizada. La elevada proporción de las escamas resistentes a la abrasión sugiere que esta paleocomunidad de condrictios estaba claramente dominada por tiburones bentónicos que habitaban sobre un sustrato rocoso. Sin embargo, uno de los niveles estratigráficos estudiados (He-20), presenta diferencias estadísticamente significativas con los demás, mostrando un porcentaje más bajo de escamas resistentes a la abrasión y un porcentaje mayor de las escamas de reducción de la fricción con el agua. Este nivel se relaciona con episodios de tormenta que pudieron haber introducido los restos de formas bento-pelágicas o pelágicas en la plataforma interna. Por último, el análisis de correlación parcial entre la abundancia relativa de los tipos funcionales de escamas y taxones en basado dientes de las mismas secciones proporcionan una correlación positiva entre los dientes de Hybodus y Pseudodalatias y escamas de reducción de la fricción con el agua, y dientes de Prolatodon y escamas resistencia a la abrasión.

Palabras clave: Triásico, condrictios, escamas, dientes, Cordillera Ibérica 


\section{Introduction}

Due to the cartilaginous nature of the chondrichthyan endoskeleton, the fossil record of this group consists mainly of disarticulated remains such as teeth, scales and fin spines. Within these elements teeth are by far the most informative in terms of taxonomy, systematics or autecology. Most of the extinct species of Chondrichthyes are described on the basis of isolated teeth (see for example monographs of Cappetta, 1987, 2012; Ginter et al., 2010 and references therein). In contrast, isolated chondrichthyan scales that commonly occur together with disarticulated teeth, provide limited taxonomic information (especially Mesozoic and Cenozoic taxa, see Reif, 1985a; Karatajute-Talimaa, 1998; Leidner and Thies, 1999; Thies and Leidner, 2011) for three main reasons: the presence of a high morphological diversity of scales in different regions of the body, which has been documented in both extant and fossil specimens (see Reif, $1973,1974,1985 a)$; the evolution of some scales of similar, or even, identical morphologies in distantly related species (Muñoz-Chápuli, 1985); and the occurrence of ontogenetic variability (Reif, 1973, 1978). As a consequence, palaeontological studies of disarticulated remains of chondrichthyans have focused on teeth and very little attention has been paid to scales. However we propose that, despite the lack of taxonomic and systematic significance, isolated scales could provide useful information regarding the palaeoecological and palaeoenvironmental conditions. Our proposal is based on the classic works of Reif $(1982$; 1985a) where the relationship between the shape and function of scales of extant sharks was pointed out. Reif (1982, 1985a) differentiated scales into five different functions: abrasion resistance, defense, drag reduction, bioluminescence and generalized functions, and indentified eight characteristic morphologies associated with these functional types. Abrasion resistant scales are found in demersal sharks, which inhabit rocky or coralline substrates and, generally, in small body regions that are often subject to abrasion in all other sharks, such as the mouth area. Scales of this type are knob-like and smooth (Morphology 1) or strongly ornamented (Morphology 2). Both types very frequently show scratch marks. Defensive scales are common in demersal sharks inhabiting muddy or sandy substrates, and protect them against ectoparasites and the settlement of epibionts. Scales of this functional type are thorn-shaped with the cusps pointing in an upward-posterior direction commonly accompanied by mucus (Morphology 3). Drag reduction scales cover most of the skin surface in fast swimming pelagic sharks. Scales of this functional type have riblets aligned in the direction of fluid flow (Morphology 4). The geometry and arrangement seem to play an important role in the drag reduction although the underlying mechanisms are not well understood yet (e.g. Bechert et al., 2000; Douglas-Dean, 2011; Raschi and Musick, 1986; Reif and Dinkelacker, 1982; Reif, 1985a). Scales associated to bioluminescence have evolved in some mesopelagic sharks, enabling the skin to carry photophores and permitting light to pass between them (Reif, 1985b). This functional type is represented by three different morphologies: square-shaped with concave facets (Morphology 5), bristle-shaped (Morphology 6) and thorn-shaped (Morphology 7). Scales with ridges and lateral cusps well developed but shorter than the principal cusp fulfill generalized functions and are found in almost all sharks (Morphology 8). Other functions related to hatching and feeding has been documented for shark scales (Grover, 1974; Reif, 1974; Southall and Sims, 2003), but they are very atypical and have not been found among our material.

In this study we firstly characterize the morphology of the five functional types proposed by Reif (1985a) using traditional morphometrics and discriminant analysis. Secondly we assign isolated placoid scales from synchronous levels of two stratigraphical sections (Middle Triassic) of the Iberian Chain (Spain), to these "functional" morphologies. The differential abundance of the functional types allow us to evaluate the structure of the chondrychtyan paleocommunity in terms of the relative dominance of more pelagic or benthic sharks and the properties of the physical environment they inhabited, such as the dominant substrate type.

\section{Material provenance}

The Middle Triassic carbonates in facies Muschelkalk (Anisian-Ladinian in age) of the eastern Iberian Chains, is represented by two trasngressive-regressive cycles showed by two carbonate units (ramps) mainly constituted by epicontinental shallow marine environments. The Cañete Fm. (López-Gómez and Arche, 1992) corresponds to the upper carbonate unit and represents the second and main marine transgression of the Middle Triassic in the southeast area of the Iberian Chains. Litologically this unit can be subdivided in two parts: a lower one, strongly dolomitized and constituted by grey massive dolomites; and an upper part, less dolomitized and mainly composed by thin-bedded bioclastic limestones, planar stromatolictic lamination, tempestite and marls levels constituting shallowing-upwards sequences (shallow inner ramp-tidal flat). The studied samples correspond to sediments of the upper part of the Cañete Fm, which has been dated as Ladinian based on ammonites, foraminifera and conodontos (López-Gómez et al., 1998). A total of 1136 isolated scales were obtained after the dissolution of Triassic carbonate rocks with $10 \%$ acetic acid from the Bugarra and Henarejos sections of the Iberian Chain (Spain). Both sections expose the dolomitic and limestone sediments of the Cañete Formation.

The Henarejos section is located $1 \mathrm{~km}$ south-east of the village of Henarejos (Province of Cuenca). Ladinian molluscs have been reported by Marquez-Aliaga (1985) and López et al. (1987). The Bugarra section is close to the village Bugarra (Province of Valencia). Márquez-Aliaga et al. (1984) studied the stratigraphy and the invertebrate paleontological aspects of this section (Fig. 1). All specimens studied herein come 


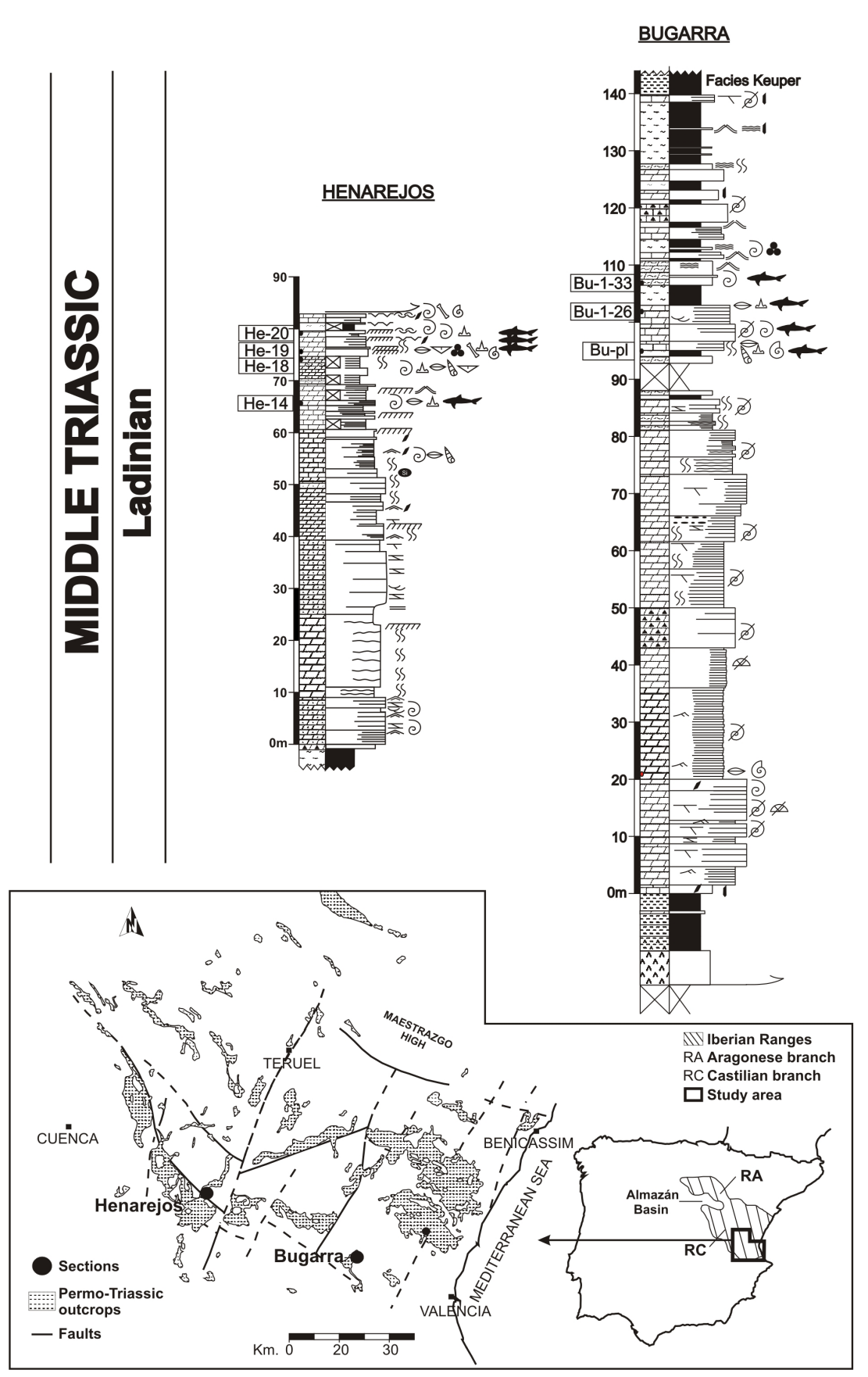

LEYEND

\begin{tabular}{|c|c|}
\hline 11 & DOLOMITE \\
\hline 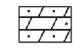 & SANDY DOLOMITES \\
\hline$\frac{11}{11}$ & MARLY DOLOMITE \\
\hline & LIMESTONE \\
\hline بك & $\begin{array}{l}\text { DOLOMITE/ } \\
\text { LIMESTONE }\end{array}$ \\
\hline & MARLS \\
\hline & LUTITE \\
\hline & BRECCIAS \\
\hline & COVERED \\
\hline$\longrightarrow$ & FAULT \\
\hline$\approx$ & WAVE RIPPLE \\
\hline & CROSS STRAT. \\
\hline & $\begin{array}{l}\text { PLANAR } \\
\text { CROSS STRAT. }\end{array}$ \\
\hline & $\begin{array}{l}\text { TROUGH } \\
\text { CROSS STRAT. }\end{array}$ \\
\hline- & CURRENT RIPPLE \\
\hline 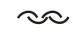 & TEMPESTITE \\
\hline$\equiv$ & PARAREL LAMINATION \\
\hline & MUD CRACKS \\
\hline$\approx$ & ALGAL LAMINATION \\
\hline & BIOTURBATION \\
\hline & SILEX NODULES \\
\hline $\mathrm{mm}$ & IRON COATED LEVEL \\
\hline 1 & EVAPORITE MOLDS \\
\hline 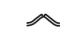 & “TEPEE” \\
\hline อ & BIOCLASTIC LEVEL \\
\hline$\leftarrow$ & CHONDRICHTHYES \\
\hline$\theta$ & BIVALVES \\
\hline & GASTEROPODS \\
\hline $\mathbf{s}$ & FORAMINIFERS \\
\hline$\nabla$ & BRACHIOPODS \\
\hline & $\begin{array}{l}\text { BIOCLASTIC } \\
\text { FRAGMENTS }\end{array}$ \\
\hline 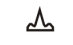 & CONODONTS \\
\hline 6 & AMMONONITES \\
\hline & $\begin{array}{l}\text { PHOSPHATIC } \\
\text { FRAGMENTS }\end{array}$ \\
\hline & CRINOIDS \\
\hline & ECHINODERMS \\
\hline
\end{tabular}

Fig. 1.- A. Geographical setting of the studied area with indication of the studied sections. B. Stratrigraphical column of Bugarra and Henarejos sections with a possible litho- and biostratigraphical correlation between them and with indication of levels that yielded the material described in this work (modified from Escudero et al., 2012).

from the uppermost member of the dolomites and limestones of the Cañete Formation (see Fig. 1) and are kept in the Museum of Geology of the University of Valencia (MGUV).

\section{Methodology}

In order to characterize the morphologies of each functional type proposed by Reif (1985a) we performed classical morphometric analysis of scales with known functions in extant sharks. Six variables (for explanation see Table 1) were measured on the dorsal surface of the scale crown from specimens figured in Reif(1985a) using ImageJ software. We used a total of 58 scales belonging to the eight scale morphologies. Each morphology was treated as a group. Discriminant analysis was performed to obtain maximum separation among the eight scale morphologies using SPSS Predictive Analytics Software Statistics (PASW) version 18.0. Three variables (LEN, WID and RID) were log-transformed to allow nonlinear combinations between them as sums or subtractions of logarithms in the discriminant functions (see below). Sub- 


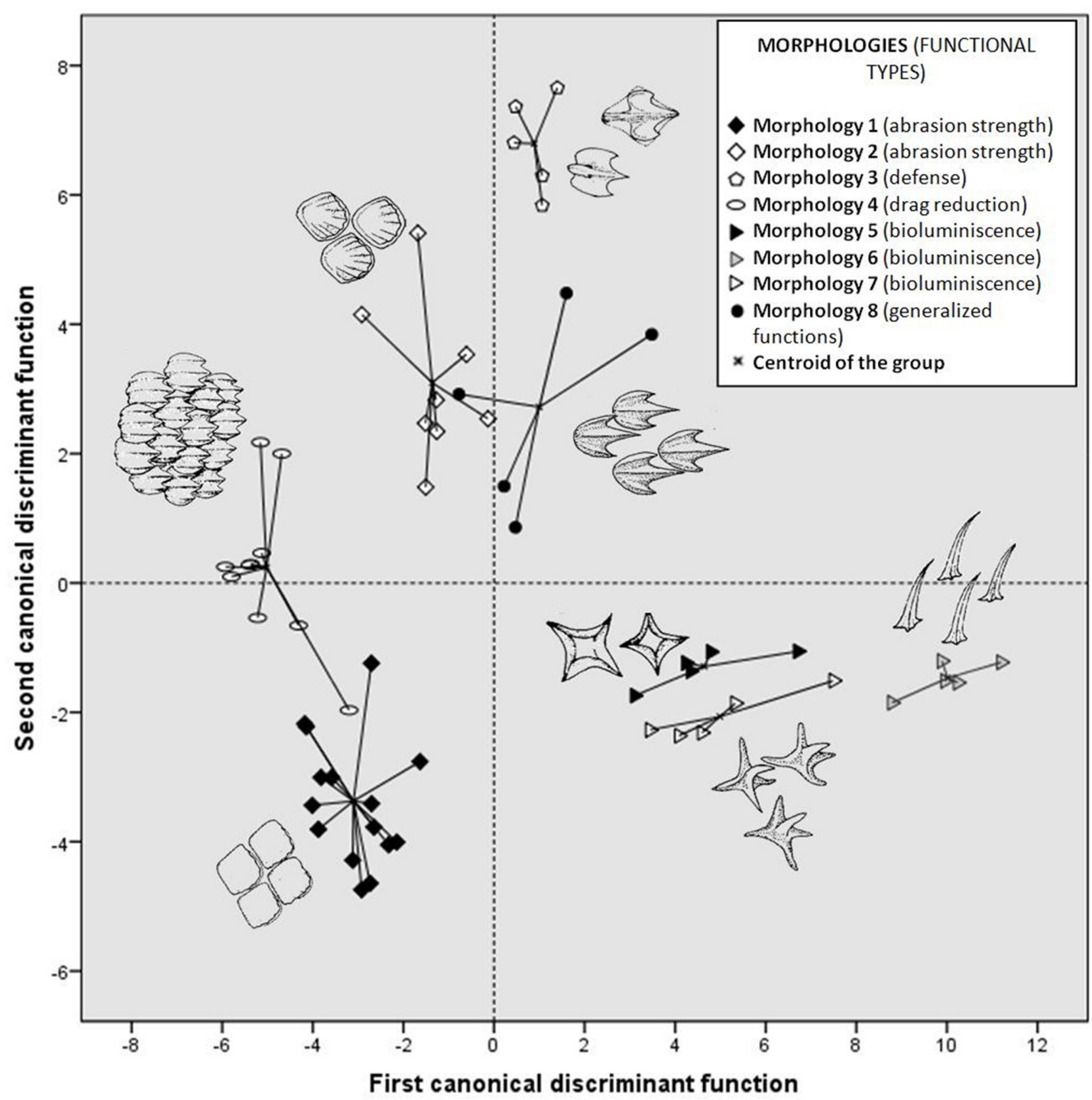

Fig. 2.- Scatter plot based on the first two discriminant functions, showing the eight scale morphologies and the five functional types.

sequently the fossil specimens were included in the discriminant analysis as unknown specimens and were assigned to one of the morphologies of functional types described by Reif (1985a) based on the similarity of their centroid values. Differential abundances of these functional types were statistically analyzed by Pearson's Chi-square test and Z-test using PASW software with the purpose of detecting differences between stratigraphic levels of the studied sections. Finally, we used Partial Correlation Analysis to compare the relative abundances of scale functional types vs. the relative abundances of tooth-based genera in the different stratigraphic levels (dates for tooth occurrences were taken from previous studies, see below). Partial Correlation Analysis allows the study of the relationship between two quantitative variables controlling the possible effect of another one that could mask correlations. Thus, the analysis was repeated four times controlling, in each case, the abundance of a concrete toothbased genus.

\begin{tabular}{ll}
\hline CIR. & Circularity $=4 \Pi\left(\right.$ area/perimeter $\left.{ }^{2}\right)$ \\
ANG. & Angle created between the two most lateral ridges $/ 2$ \\
PA & Presence or absence of ridges \\
LEN. & Maximum length of the scale \\
WID. & Maximum width of the scale \\
RID. & Average length of ridges
\end{tabular}

Table 1. Explanation and coded designations of measured scale characters.

\begin{tabular}{lcccccc}
\hline \multicolumn{7}{c}{ Function } \\
\hline Variable & $\mathbf{1}$ & $\mathbf{2}$ & $\mathbf{3}$ & $\mathbf{4}$ & $\mathbf{5}$ & $\mathbf{6}$ \\
\hline CIR. & -0.967 & -0.304 & 0.179 & -0.458 & -0.168 & 0.187 \\
ANG. & 1.303 & 1.960 & 5.761 & 1.489 & 0.748 & 0.946 \\
PA & 7.460 & -8.598 & 7.560 & 5.703 & 0.657 & -7.984 \\
Log (LEN.) & 0.609 & -0.389 & 0.656 & -1.191 & -1.061 & -0.349 \\
Log (WID.) & -0.391 & 0.175 & -0.691 & 1.694 & 0.108 & -0.229 \\
Log (RID.) & -6.266 & 11.025 & -1.864 & -4.311 & 0.362 & 8.077 \\
\hline
\end{tabular}

Table 2. Standarized canonical discriminant function coefficients. 


\section{Results and Discussion}

\subsection{Discriminant analysis using scales of extant sharks.}

Canonical variate analysis generated six discriminant functions. Coefficients, eigenvalues, proportion of explained variance and canonical correlation are presented in Tables 2 and 3. The first canonical discriminant function explains $53.6 \%$ of the total variance while the second one accounts for $25.8 \%$ of the total variance ( $79.5 \%$ cumulative variance). The plot of the two canonical variables illustrates a good separation between the eight morphologies proposed by Reif (1985a) (Fig. 2). The discriminant analysis correctly classifies $100 \%$ of original cases, while the percentage of cross-validated grouped cases correctly classifies $93.1 \%$ (i.e. 54 of the 58 scales) (Table 4). In this analysis, scales of morphologies 1, 2, 4 and 7 are the most correctly classified followed by scales of morphology 8 . The least correctly classified are the scales of morphologies 3 and 6 (Table 4).

These results show that classical morphometric analysis is able to discriminate between the five functional types of chondrichthyan scales proposed by Reif (1985a) using six variables in the discriminant functions. In addition, we also tested other alternatives to the use of the classical morphometric analysis, like geometric morphometrics or Fourier analysis, but the results were not as good as expected. Due to the high morphological variability in scales, it was very difficult to set homologous points in the eight scale morphologies and, therefore, it was not possible to apply geometric morphometrics in an acceptable way. On the other hand, Fourier analysis only takes into account characters reflected in the contour of the scales without considering other features, as for example those related to the ridges, which might be useful to differentiate between groups. Although the results of this method are good, with the percentage of cross-validated grouped cases correctly classified ranging from $42.2-80 \%$ depending on the number of harmonics and the type of analysis

\begin{tabular}{ccccc}
\hline Function & Eigenvalue & $\begin{array}{c}\text { \% of } \\
\text { Variance }\end{array}$ & $\begin{array}{c}\text { Cumulative } \\
\text { \% of } \\
\text { Variance }\end{array}$ & $\begin{array}{c}\text { Canonical } \\
\text { Correlation }\end{array}$ \\
\hline $\mathbf{1}$ & 23.079 & 53.6 & 53.6 & 0.979 \\
$\mathbf{2}$ & 11.115 & 25.8 & 79.5 & 0.958 \\
$\mathbf{3}$ & 5.124 & 11.9 & 91.4 & 0.915 \\
$\mathbf{4}$ & 2.910 & 6.8 & 98.1 & 0.863 \\
$\mathbf{5}$ & 0.639 & 1.5 & 99.6 & 0.624 \\
$\mathbf{6}$ & 0.168 & 0.4 & 100.0 & 0.379 \\
\hline
\end{tabular}

Table 3. Eigenvalues, proportion of explained variance and canonical correlation of the discriminant functions.

(polar or elliptic), they are not as accurate as those obtained by classical morphometric analysis (Appendix 1 shows results obtained using Fourier analysis).

\subsection{Discriminant analysis including fossil specimens.}

Once the discriminant analysis was established, the 1136 fossil scales from the Henarejos and Bugarra sections were included as unknowns. Following the predictions obtained, fossil scales were assigned to four morphologies belonging to three of Reif's functional types (Fig. 3). 289 fossil specimens $(25 \%)$ were identified as abrasion resistant, 705 (62 $\%)$ as drag reducing and $142(13 \%)$ were identified as scales of generalized functions. None of the fossil scales were assigned to either bioluminescence type (morphologies 5, 6 and 7) or to the defense type (morphology 3). Abundances of each functional type by section and stratigraphic level are shown in Table 5.

When it is taken into consideration that in pelagic sharks scales for abrasion resistance are restricted only to small areas of the body (e.g. surrounding the mouth) representing less than $5 \%$ of the total body surface, the high proportion of scales with a protective function against abrasion present

\begin{tabular}{|c|c|c|c|c|c|c|c|c|c|}
\hline \multicolumn{10}{|c|}{ Predicted group } \\
\hline & Morphology 1 & Morphology 2 & Morphology 3 & Morphology 4 & Morphology 5 & Morphology 6 & Morphology 7 & Morphology 8 & TOTAL \\
\hline Morphology 1 & $\begin{array}{c}5 \\
(100.0)\end{array}$ & $\begin{array}{c}0 \\
(0.0)\end{array}$ & $\begin{array}{c}0 \\
(0.0)\end{array}$ & $\begin{array}{c}0 \\
(0.0)\end{array}$ & $\begin{array}{c}0 \\
(0.0)\end{array}$ & $\begin{array}{c}0 \\
(0.0)\end{array}$ & $\begin{array}{c}0 \\
(0.0)\end{array}$ & $\begin{array}{c}0 \\
(0.0)\end{array}$ & $\begin{array}{c}5 \\
(100.0)\end{array}$ \\
\hline Morphology 2 & $\begin{array}{c}0 \\
(0.0)\end{array}$ & $\begin{array}{c}5 \\
(100.0)\end{array}$ & $\begin{array}{c}0 \\
(0.0)\end{array}$ & $\begin{array}{c}0 \\
(0.0)\end{array}$ & $\begin{array}{c}0 \\
(0.0)\end{array}$ & $\begin{array}{c}0 \\
(0.0)\end{array}$ & $\begin{array}{c}0 \\
(0.0)\end{array}$ & $\begin{array}{c}0 \\
(0.0)\end{array}$ & $\begin{array}{c}5 \\
(100.0)\end{array}$ \\
\hline Morphology 3 & $\begin{array}{c}0 \\
(0.0)\end{array}$ & $\begin{array}{c}1 \\
(20.0)\end{array}$ & $\begin{array}{c}4 \\
(80.0)\end{array}$ & $\begin{array}{c}0 \\
(0.0)\end{array}$ & $\begin{array}{c}0 \\
(0.0)\end{array}$ & $\begin{array}{c}0 \\
(0.0)\end{array}$ & $\begin{array}{c}0 \\
(0.0)\end{array}$ & $\begin{array}{c}0 \\
(0.0)\end{array}$ & $\begin{array}{c}5 \\
(100.0)\end{array}$ \\
\hline Morphology 4 & $\begin{array}{c}0 \\
(0.0)\end{array}$ & $\begin{array}{c}0 \\
(0.0)\end{array}$ & $\begin{array}{c}0 \\
(0.0)\end{array}$ & $\begin{array}{c}15 \\
(100.0)\end{array}$ & $\begin{array}{c}0 \\
(0.0)\end{array}$ & $\begin{array}{c}0 \\
(0.0)\end{array}$ & $\begin{array}{c}0 \\
(0.0)\end{array}$ & $\begin{array}{c}0 \\
(0.0)\end{array}$ & $\begin{array}{c}15 \\
(100.0)\end{array}$ \\
\hline Morphology 5 & $\begin{array}{c}0 \\
(0.0)\end{array}$ & $\begin{array}{c}0 \\
(0.0)\end{array}$ & $\begin{array}{c}0 \\
(0.0)\end{array}$ & $\begin{array}{c}0 \\
(0.0)\end{array}$ & $\begin{array}{c}7 \\
(87.5)\end{array}$ & $\begin{array}{c}1 \\
(12.5)\end{array}$ & $\begin{array}{c}0 \\
(0.0)\end{array}$ & $\begin{array}{c}0 \\
(0.0)\end{array}$ & $\begin{array}{c}8 \\
(100.0)\end{array}$ \\
\hline Morphology 6 & $\begin{array}{c}0 \\
(0.0)\end{array}$ & $\begin{array}{c}0 \\
(0.0)\end{array}$ & $\begin{array}{c}0 \\
(0.0)\end{array}$ & $\begin{array}{c}0 \\
(0.0)\end{array}$ & $\begin{array}{c}0 \\
(0.0)\end{array}$ & $\begin{array}{c}4 \\
(80.0)\end{array}$ & $\begin{array}{c}1 \\
(20.0)\end{array}$ & $\begin{array}{c}0 \\
(0.0)\end{array}$ & $\begin{array}{c}5 \\
(100.0)\end{array}$ \\
\hline Morphology 7 & $\begin{array}{c}0 \\
(0.0)\end{array}$ & $\begin{array}{c}0 \\
(0.0)\end{array}$ & $\begin{array}{c}0 \\
(0.0)\end{array}$ & $\begin{array}{c}0 \\
(0.0)\end{array}$ & $\begin{array}{c}0 \\
(0.0)\end{array}$ & $\begin{array}{c}0 \\
(0.0)\end{array}$ & $\begin{array}{c}5 \\
(100.0)\end{array}$ & $\begin{array}{c}0 \\
(0.0)\end{array}$ & $\begin{array}{c}5 \\
(100.0)\end{array}$ \\
\hline Morphology 8 & $\begin{array}{c}0 \\
(0.0)\end{array}$ & $\begin{array}{c}0 \\
(0.0)\end{array}$ & $\begin{array}{c}0 \\
(0.0)\end{array}$ & $\begin{array}{c}1 \\
(10.0)\end{array}$ & $\begin{array}{c}0 \\
(0.0)\end{array}$ & $\begin{array}{c}0 \\
(0.0)\end{array}$ & $\begin{array}{c}0 \\
(0.0)\end{array}$ & $\begin{array}{c}9 \\
(90.0)\end{array}$ & $\begin{array}{c}10 \\
(100.0)\end{array}$ \\
\hline
\end{tabular}

Table 4. Count (Non-italic numbers) and percentages (Italic numbers) of cross-validated grouped cases correctly classified. 

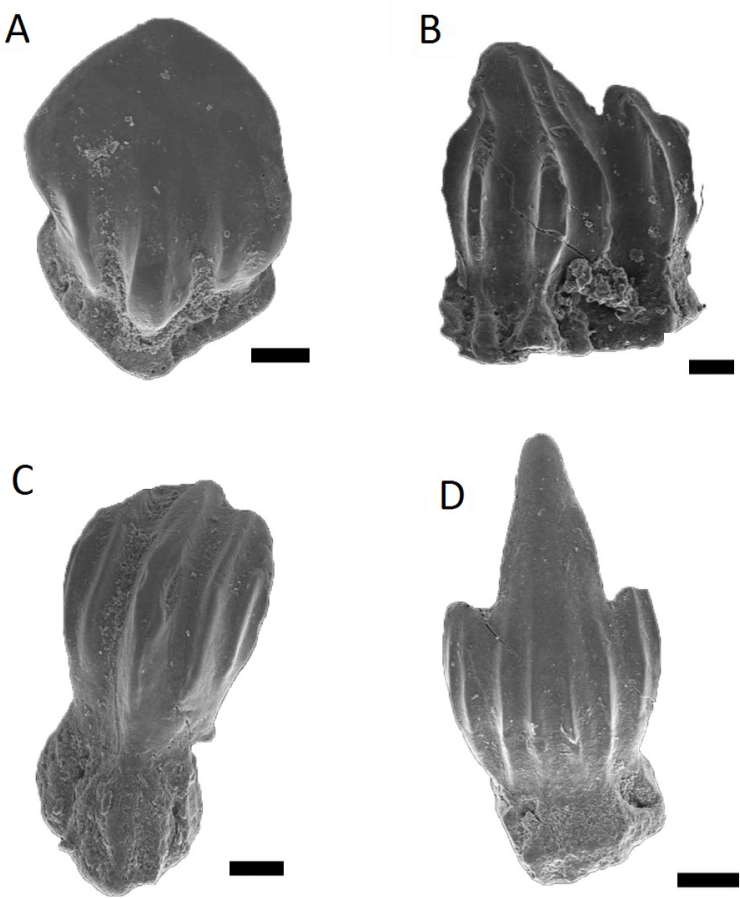

Fig. 3.- Morphologies of fossil scales from Henarejos and Bugarra sections. A: MGUV-24.804. Morphology 1 (Abrasion resistant scales) in upper-frontal view. B: MGUV-24.799. Morphology 2 (Abrasion resistant scales) in frontal view. C: MGUV-24.798. Morphology 4 (Drag reduction scales) in frontal view. D: MGUV- 24.803. Morphology 8 (Scales with generalized functions) in frontal view. Scales: A, C, 500 $\mu \mathrm{m} . ; \mathrm{B}, 100 \mu \mathrm{m} . ; \mathrm{D}, 200 \mu \mathrm{m}$.

in our association become interesting for the interpretation of the data. It could be reasonably related with the presence of a high number of benthic sharks, in which (especially in those living on hard sea floor) abrasion resistant scales cover not only the mouth area but also half of the ventral part of the body and the ventral and anterior areas of the pectoral and pelvic fins (Reif, 1985a). Thus, our results indicate that the Middle Triassic chondrichthyan community from the Iberian Chain was dominated by benthic sharks. This suggests a palaeoenvironmental interpretation as an area of shallow marine waters, probably dominated by an abrasive substrate (such as a near-shore hard sea floor environment or some type of lagoon). Noticeably, this interpretation is in accordance with sedimentological data from previous studies in the area (e.g. Marquez-Aliaga et al. 1984; López-Gómez et al., 1993), providing an independent line of evidences that validate our analysis.

\subsection{Pearson's Chi-square test and Z-test.}

Pearson's Chi-square test showed significant differences between levels of the Bugarra and Henarejos sections ( $\mathrm{p}=$ 0.000 Table 5). Z-test allowed us to detect between what levels and in which concrete functional types significant differences occur (Table 6). The test show significant differences between level He-20 and the remaining levels. The percentage of abrasion resistant scales is significantly lower than in all others levels and the percentage of drag reduction scales is significantly higher than in four of the other seven levels $(\mathrm{Bu}$ 1-33, Bu 1-26, Bu1-26d and He-18). This suggests a change in the composition of the chondrichthyan community with an increase of the pelagic or bentho-pelagic forms. In fact the fraction of abrasion resistant scales $(5.2 \%)$ is close to the expectation for pelagic sharks. Furthermore teeth of supposed benthic taxa (see below) do not occur in this level. These changes could be explained by (1) punctuated changes in the bathymetry of the basin related to transgressive-regressive pulses that produce a deepening and a displacement of the coastline] or (2) by storm episodes that introduce these communities from deeper waters into the inner platform, where sediments of level He-20 were deposited. Sedimentological dates more likely support the second scheme. According with this dates all the levels of Henarejos section correspond with shallow marine environments within the inner platform, without evidence of any punctual deepening. Moreover, in the top levels of the stratigraphical sequence different tempestite levels are recorded, just above the He-20 level.

\subsection{Correlation with fossil teeth.}

Previous studies (Pla et al., 2009; 2013) on isolated teeth from the same samples that the scales of this study identified the following tooth based species: Palaeobates angustissimus (Agassiz, 1838), Pseudodalatias henarejensis Botella, Plasencia, Márquez-Aliaga, Cuny and Dorka, 2010; Hybodus bugarensis Pla, Márquez-Aliaga and Botella, in press; Prolatodon bucheri (Cuny, Rieppel and Sander, 2001); Prolatodon contrarius (Johns, Barnes and Orchard, 1997); Hybodus plicatilis Agassiz, 1838; and Lissodus aff. lepagei (Fig. 4). Partial correlation analysis between the relative abundances of functional types of scales and abundances of tooth-based taxa at generic level indicates positive correlation between teeth of Hybodus and Pseudodalatias and drag reduction scales, and teeth of Prolatodon and abrasion resistant scales. A negative correlation was present between teeth of Prolatodon and drag reduction scales (Table 7). Once more, these results are in agreement with the palaeobiological interpretations based on the tooth morphology (see Pla et al., 2013). Thus, dentitions of Prolatodon bucheri and Prolatodon contrarius can be identified as belonging to a grasping-crushing feeding strategy (following the terminology of Cappetta, 1986, 1987) with cuspidate anterior teeth and flat lateral teeth. This dental type (present generally in sharks of benthic habits) corresponds to a trophic adaptation for durophagy and indicates crustaceans, ostracods, or shelled invertebrates such as gastropods and bivalves as the preferred prey. In consequence, the obtained positive correlation between Prolatodon and abrasion strength scales is expected. In addition, Pseudodalatias exhibited a cutting-clutching dentition extremely similar to those of some extant neoselachian Dalatiidae (Gray, 1851). The feeding preferences of dalatiids consist of "parasitic" bites excising portions of flesh from large-size oceanic ani- 


\begin{tabular}{|c|c|c|c|c|c|c|c|c|c|}
\hline \multirow[t]{3}{*}{$\mathbf{A}$} & \multicolumn{9}{|c|}{ Level } \\
\hline & & \multicolumn{2}{|c|}{ Не - 14} & \multicolumn{2}{|c|}{ Нe - 18} & \multicolumn{2}{|c|}{ Не - 19} & \multicolumn{2}{|c|}{ Не - 20} \\
\hline & & Count & $\%$ & Count & $\%$ & Count & $\%$ & Count & $\%$ \\
\hline \multirow{4}{*}{$\begin{array}{c}\text { Functional } \\
\text { type }\end{array}$} & $\begin{array}{l}\text { Abrasion } \\
\text { strength }\end{array}$ & 32 & 22.9 & 90 & 46.2 & 31 & 16.4 & 10 & 5.2 \\
\hline & $\begin{array}{l}\text { Drag } \\
\text { reduction }\end{array}$ & 96 & 68.6 & 96 & 49.2 & 137 & 72.5 & 152 & 79.6 \\
\hline & $\begin{array}{l}\text { Generalized } \\
\text { functions }\end{array}$ & 12 & 8.6 & 9 & 4.6 & 21 & 11.1 & 29 & 15.2 \\
\hline & TOTAL & 140 & 100 & 195 & 100 & 189 & 100 & 191 & 100 \\
\hline \multirow[t]{3}{*}{ B } & \multicolumn{9}{|c|}{ Level } \\
\hline & & \multicolumn{2}{|c|}{ Bu 1 - 33} & \multicolumn{2}{|c|}{ Bu - pl } & \multicolumn{2}{|c|}{ Bu $1-26$} & \multicolumn{2}{|c|}{ Bu 1 - 26d } \\
\hline & & Count & $\%$ & Count & $\%$ & Count & $\%$ & Count & $\%$ \\
\hline \multirow{4}{*}{$\begin{array}{c}\text { Functional } \\
\text { type }\end{array}$} & $\begin{array}{l}\text { Abrasion } \\
\text { strength }\end{array}$ & 13 & 39.4 & 18 & 21.7 & 10 & 41.7 & 85 & 30.2 \\
\hline & $\begin{array}{l}\text { Drag } \\
\text { reduction }\end{array}$ & 16 & 48.5 & 60 & 72.3 & 10 & 41.7 & 138 & 49.1 \\
\hline & $\begin{array}{l}\text { Generalized } \\
\text { functions }\end{array}$ & 4 & 12.1 & 5 & 6.0 & 4 & 16.7 & 58 & 20.6 \\
\hline & TOTAL & 33 & 100 & 83 & 100 & 24 & 100 & 281 & 100 \\
\hline
\end{tabular}

Table 5. Count of scales (Non-italic numbers) and differential abundance (Italic numbers) of each functional type by levels and sections (A: Henarejos; B: Bugarra).

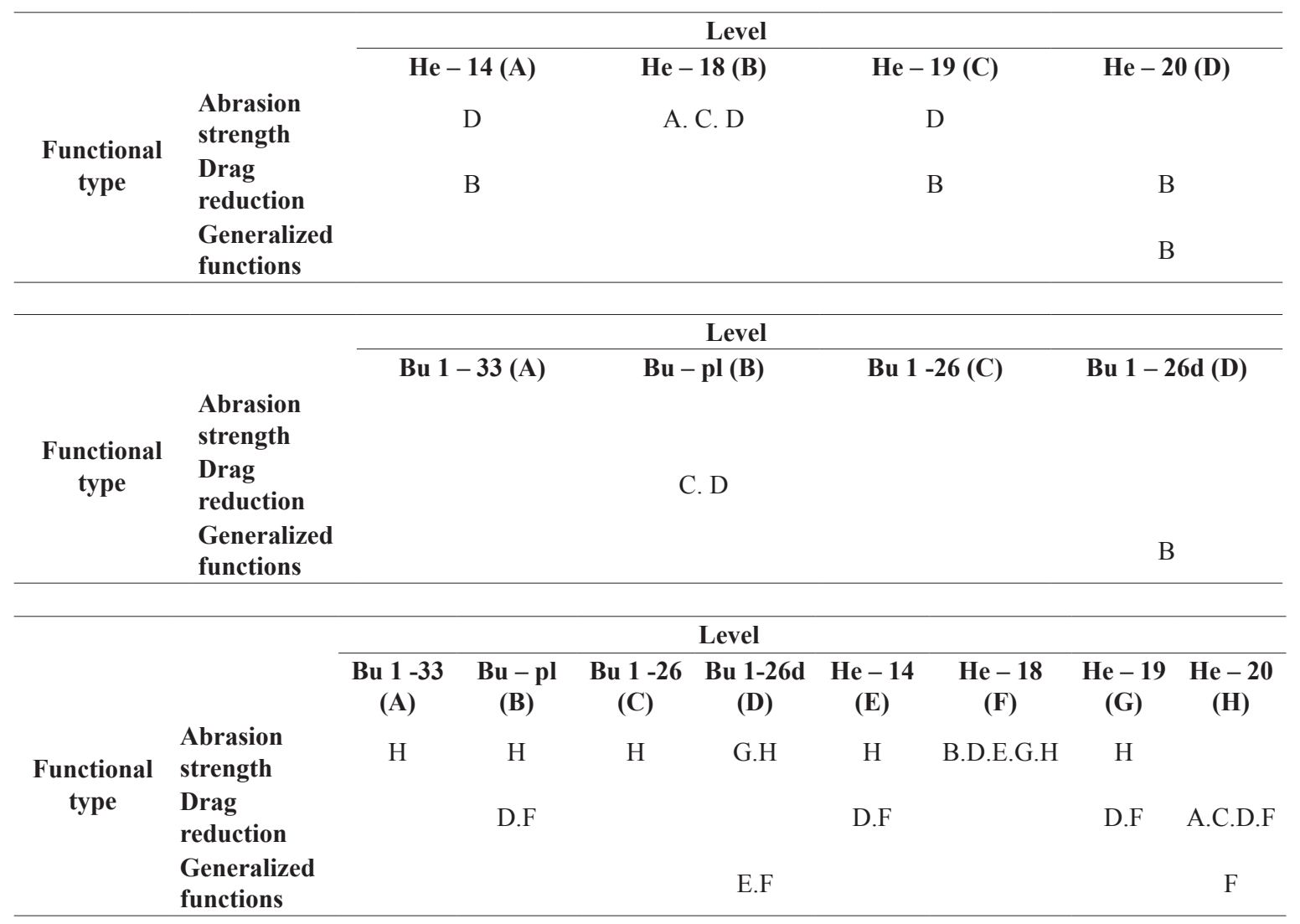

Table 6. Z-test results based on two-sided tests with a significance level 0.05 . For each significant pair, the key of the category with the smaller column proportion appears under the category with the larger column proportion. 
Table 7. Partial correlation analysis results between fossil teeth and functional types of scales. Significant correlations are identified with a single asterisk (A: Control variable Prolatodon; B: Control variable Lissodus; C: Control variable Pseudodalatias; D: Control variable Hybodus).

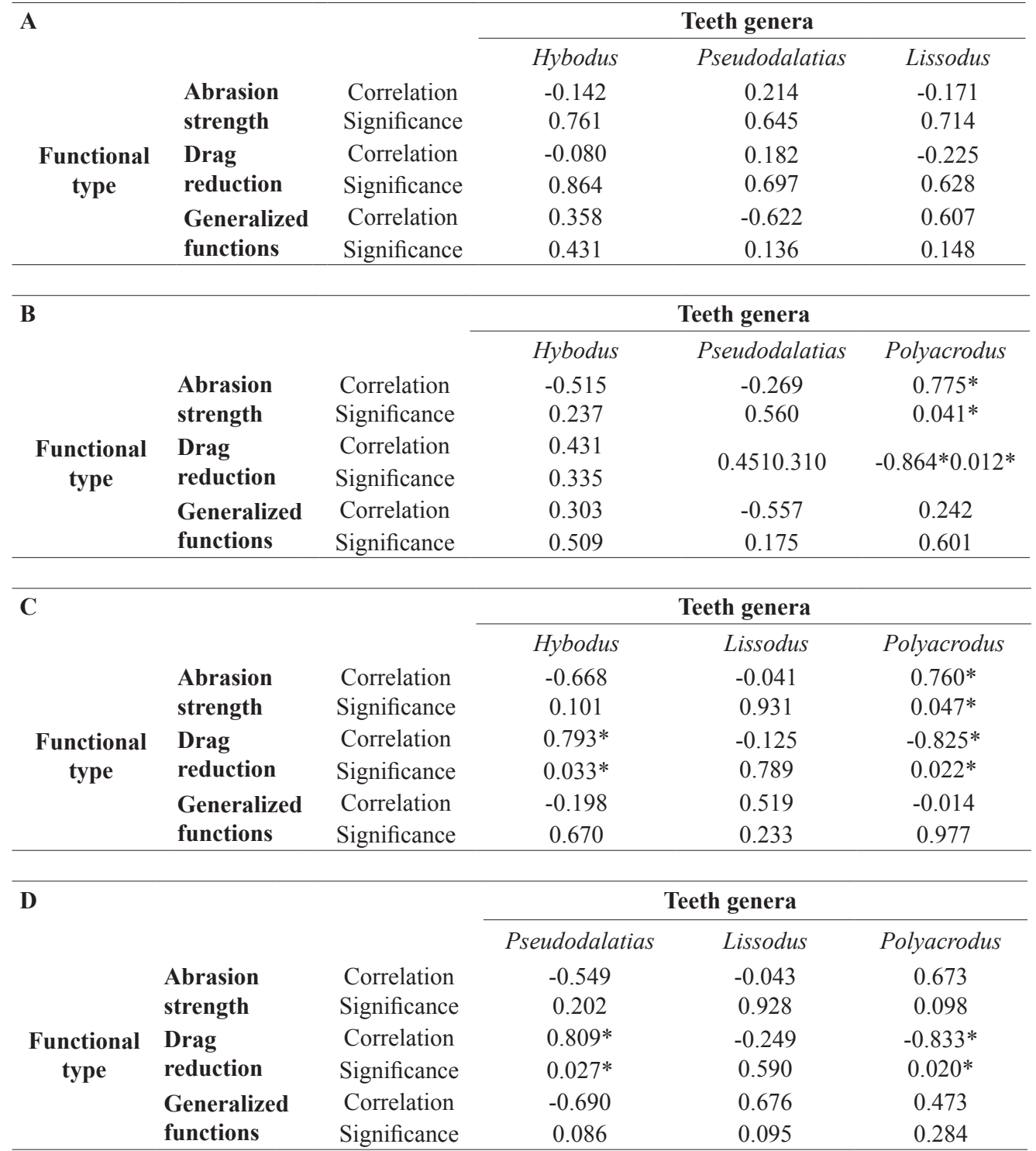

mals, including other sharks, marine mammals and bony fishes (Gasparini and Sazima, 1996; Soto and Mincarone, 2001; Heithaus, 2004; Heithaus and Vaudo, 2012). This trophic behavior is favoured by sharks with a bentho-pelagic swimming mode that look for prey in the water column. Therefore, the positive correlation between teeth of Pseudodalatias and drag reduction scales was also predictable. Finally, the multicuspidate teeth of hybodonts are considered to be adapted for a "grasping and swallowing" strategy (clutching- or tearingtype sensu Cappetta, 1987) that could include prey such us other small fishes, soft-bodied animals and arthropods. This strategy is present in both pelagic (as in some Isurus) and benthic sharks (such as Scyliorhinidae or Squatinidae, Cappetta, 1987). The positive correlation found between Hybodus teeth, which almost all belong to the species $H$. plicatilis, and scales of the drag reduction type indicate that this widespread shark - known from Germany (Agassiz, 1843), Switzerland (Meyer, 1849; Rieppel, 1981; Scheinpflug, 1984) Spain (Pla et al., 2009; 2013) and Saudi Arabia (Vickers et al., 1999) was a bentho-pelagic to pelagic swimmer.

It is important to remark, that the good statistical correlation found between the abrasion resistant scales and durophag tooth-based taxa (that putatively belonging to benthonic sharks), and the high correlation between cutting teeth and drag reduction scales (that could belong to more pelagic shark), strongly supports the idea that no taphonomic bias affect significantly the relative abundance of the different type scales, and hence our final results.

\section{Conclusions}

Classical morphometric analysis has been able to discriminate among the eight morphologies, included in five functional types, of chondrichthyan scales proposed by Reif (1985a). A high percentage of cross-validated grouped cases were correctly classified $(93.1 \%)$. This strongly supports a 
A

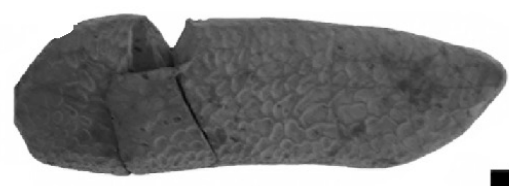

B

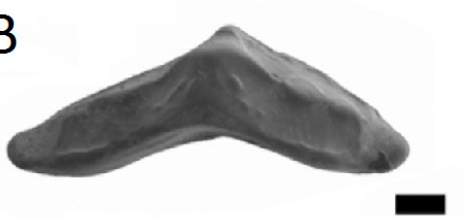

C

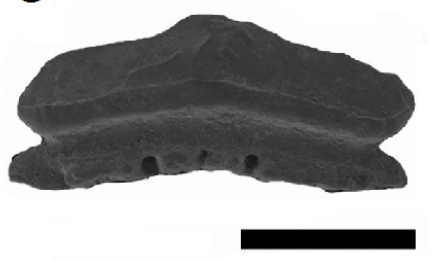

$E$
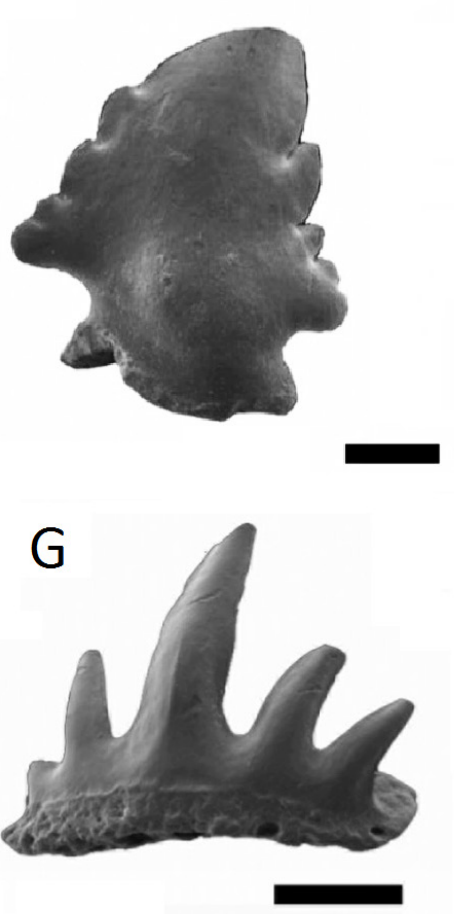
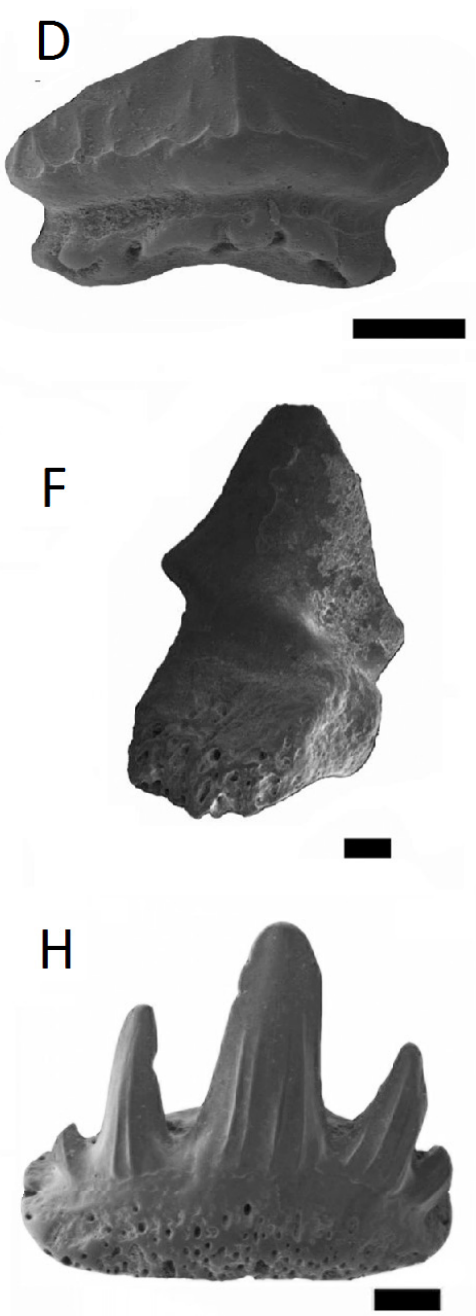

Fig. 4.- Fossil teeth from Henarejos and Bugarra sections (from Pla et al., 2013). A: MGUV 25791. Palaeobates angustissimus, occlusal view, Bugarra section. B: MGUV 25854. Lissodus aff. L. lepagei, lingual view, Bugarra section. C: MGUV 25822. Prolatodon contrarius, labial view, Henarejos section. D: MGUV 25796. Prolatodon bucheri, labial view, Bugarra section. E: MGUV 25868. Pseudodalatias henarejensis, lower tooth in labial view, Henarejos section. F: MGUV 25869. Pseudodalatias henarejensis, upper tooth in lingual view, Henarejos section. G: MGUV 25831. Hybodus bugarensis, labial view, Henarejos section. H: MGUV 25837. Hybodus plicatilis, labial view, Bugarra section. Scales: $200 \mu \mathrm{m}$. high possibility of correct identification when the discriminant functions are applied to isolated fossil scales.

A total number of 1136 isolated chondrichthyan scales were collected from two Middle Triassic sections (Henarejos and Bugarra) of the Iberian Chain. They were included in the discriminant analysis resulting in the identification of $25 \%$ as abrasion resistant, $62 \%$ as drag reduction and 13 $\%$ as scales of generalized functions. Neither the scales of the bioluminescent nor the defensive type defined by Reif (1985a) could be recognized. The elevated proportion of abrasion resistant scales indicates that the chondrichthyan palaeocommunity from the Middle Triassic of the Iberian Chain was dominated by sharks adapted to a benthic lifestyle. This is in agreement with palaeobiological interpretations provided by previous analyses of isolated chondrichthyan teeth from the same sections (Pla et al., 2013) which show that in terms of diversity, the chondrichtyan fauna was dominated by durophagous sharks most of them with grasping-crushing dentitions. Dentitions of this type imply feeding preferences including crustaceans, ostracods and shelled invertebrates (gastropods and bivalves), and they are currently present in sharks which live in close relationship with the substrate bottom looking for their prey. Thus, in our opinion, the high percentage of abrasion resistant scales (i.e. of benthic sharks) could be likely related with a palaeoenvironment of shallow marine waters, mostly dominated by a rough substrate, such as a rocky shore platform. This interpretation based on isolated scales is in agreement with sedimentological and other paleontological studies in the area (see e.g. Márquez-Aliaga et al., 1984; MárquezAliaga and López-Goméz, 1989; López-Gómez and Arche, 1992; López-Gómez et al., 1993 among others). 
The statistical analyses results in differences between level He-20 (Henarejos section) and all other levels concerning the relative abundance of the functional types of scales. The percentage of the abrasion resistant type in this single level is significantly lower but that of drag reduction scales significantly higher. This can be linked with punctuated storm episodes that transported remains of allochthonous chondrichthyan community with an increase in pelagic forms. Finally, the partial correlation analysis between the relative abundances of functional types of scales and tooth-based taxa allowed the detection of a positive correlation between teeth of Hybodus and Pseudodalatias and drag reduction scales, and teeth of Prolatodon and scales of the abrasion resistant In summary, our analyses show that, despite their limited taxonomic value, isolated scales can be a useful tool for palaeoenvironmental and palaeoecological inferences of the chondrichthyan palaeocommunity. The good concordance of the results obtained from morphometric discriminant analysis of chondrichthyan scales from the Middle Triassic of the Iberian Chains with inferences based on isolated teeth and sedimentological data suggest that this methodology can be extrapolated for studies in other localities.

\section{Acknowledgments}

This work has been supported by the Program 458.10/2007 and /2008 from Conselleria de Cultura, Educació i Esports (Generalitat Valenciana) and by Grant BFU2008-00643 to D.R.G. from the Spanish Ministerio de Ciencia e Innovación. We thank Dr. Soledad de Esteban (Institut Català de Paloentologia) and an anonymous reviewer their helpful comments that have improved considerably the original manuscript; and Dr. John Cunningham (University of Bristol) for review and improve the English. CMP benefits from a postdoctoral contract Marie Curie FP7-People IEF 2011-29968.

\section{References}

Agassiz, L. (1833-44): Recherches sur les poissons fossiles, 3. Imprimerie de Petitpierre, Neuchâtel 32: 390 p.

Botella, H., Plasencia, P., Márquez-Aliaga, A., Cuny, G., Dorka, M. (2009): Pseudodalatias henarejensis nov. sp. A new Pseudodalatiid (Elasmobranchii) from the Middle Triassic of Spain. Journal of Vertebrate Paleontology 29(4), 1006-1012. doi: 10.1671/039.029.0425

Bechert, D. W., Bruse, M., Hage, W. (2000): Experiments with threedimensional riblets as an idealized model of shark skin. Experiments in Fluids 28(5), 403-412. doi: 10.1007/s003480050400

Cappetta, H. (1986): Types dentaires adaptatifs chez les sélaciensactuels et post-paléozoiques. Palaeovertebrata 16, 57-76.

Cappetta, H. (1987): Chondrichthyes II, Mesozoic and Cenozoic Elasmobranchii. Handbook of Paleoichthyology. Verlag Dr. Friedrich Pfeil, München: 193 p.

Cappetta, H. (2012): Chondrichthyes, Mesozoic and Cenozoic Elasmobranchii: Teeth. Handbook of Paleoichthyology. Verlag Dr. Friedrich Pfeil, München: 521 p.

Cuny, G., Rieppel, O., Sander, P.M. (2001): The shark fauna from the Middle Triassic (Anisian) of North-Western Nevada. Zoological Journal of the Linnean Society 13, 285-30. doi: 10.1111/j.1096- 3642.2001.tb00627.x

Douglas-Dean, B. (2011): The effect of shark skin inspired riblet geometries on drag in rectangular duct flow. Master thesis. Ohio: $86 \mathrm{p}$.

Escudero M.J., Pla, C., Botella, H., Márquez-Aliaga, A. (2012): Situación estratigráfica de tiburones del Triásico Medio de la Cordillera Ibérica. En: XXVIII Jornadas de la Sociedad Española de Paleontología y Simposios de los Proyectos no 587 y 569 del PICG. Valencia y Sóller, 1-6 de octubre de 2012. Homenaje a Guillem Colom Casasnovas (1900-1993). Libro de Resúmenes (eds. Liao, J. C., Gámez Vintaned, J.A:, Valenzuela-Ríos, J.I. \& García-Forner, A.) Universitat de València, Valencia; Sociedad Española de Paleontología, Madrid, 217-220.

Gasparini, J. L., Sazima, I. (1996): A stranded melonheaded whale, Peponocephala electra, in southeastern Brazil, with comments on wounds from the cookiecutter shark Isistius brasiliensis. Marine Mammal Science 12, 308-312. doi: 10.1111/j.1748-7692.1996. tb00582.x

Ginter, M., Hampe, O., Duffin, C. J. (2010): Chondrichthyes. Paleozoic Elasmobranchii: Teeth. Handbook of Paleoichthyology. Verlag Dr. Friedrich Pfeil, München: 168 p.

Gray, J. E. (1851): List of the specimens of fish in the collection of the British Museum. Part 1. Chondropterygii. British Museum (Natural History), London: $160 \mathrm{p}$.

Grover, C. A. (1974): Juvenile denticles of the swell shark Cephaloscyllium ventriosum: function in hatching. Canadian Journal of Zoology 52, 359-363. doi: 10.1139/z74-043

Heithaus, M. R. (2004): Predator-prey interactions. In: J.C. Carrier, J.A. Musick, M.R. Heithaus (eds), Biology of Sharks and their Relatives CRC Press, Boca Raton, FL, USA: 487-521.

Heithaus M.R., Vaudo, J.J. (2012): Predator-prey interactions. In: J.C. Carrier, J.A. Musick, M.R. Heithaus (eds), Biology of Sharks and their Relatives CRC Press, Boca Raton, FL, USA: 505-546.

Johns, M. J., Barnes, C. R., Orchard M. J. (1997): Taxonomy and Biostratigraphy of Middle and Late Triassic elasmobranch ichthyoliths from northeastern British Columbia. Geological Survey of Canada $502,1-235$.

Karatajuté -Talimaa, V. (1998): Determination methods for the exoskeletal remains of early vertebrates. Mitteilungen ausdem Museum für Naturkunde in Berlin, Geowissenschaftliche Reihe 1, 21-52. doi:10.1002/mmng.19980010103

Leidner, A., Thies, D. (1999): Placoid scales and oral teeth of Late Jurassic elasmobranchs from Europe. Mesozoic Fishes 2 - Systematics and Fossil Record: 29-40.

López-Gómez, J., Arche, A. (1992): Las unidades litoestratigráficas del Pérmico y Triásico Inferior y Medio en el sector SE de la Cordillera Ibérica. Estudios Geológicos 48, 123-143.

López-Gómez, J., Márquez-Aliaga, A., Arche, A., Goy, A. (1987): La facies Muschelkalk de Henarejos (Cuenca): sedimentología y fauna del tramo superior. Cuadernos de Geología Ibérica 11, 665-676.

López-Gómez, J., Mas, R., Arche, A. (1993): The evolution of the Middle Triassic (Muschelkalk) carbonate ramp in the SE Iberian Ranges, Eastern Spain: sequence stratigraphy, dolomitization processes and dynamic controls. Sedimentary Geology 87, 165-193.

López-Gómez, J., Arche, A., Calvet, F., Goy, A. (1998): Epicontinental marine carbonate sediments of the Middle and Upper Triassic in the westermost part of the Tethys Sea, Iberian Peninsula. Zentralblatt für Geologie und Paläontologie 9-10, 1033-1084.

Márquez-Aliaga, A. 1985. Bivalvos del Triásico Medio del Sector Meridional de la Cordillera Ibérica y de los Catalánides. Colección Tesis Doctorales. Editorial de la Universidad Complutense de Madrid 40: 429 pp.

Márquez-Aliaga, A., De Santisteban, C., Márquez, L. (1984): Triásico Medio de Bugarra. Estudios Geológicos 40, 365-374.

Márquez-Aliaga, A., López Gómez, J. (1989): Paleontología y ambientes 
sedimentarios del Triásico medio, Muschelkalk, de la Cordillera Ibérica 1: Cuencas y Valencia. España. Estudios geológicos 45, $387-$ 398.

Márquez-Aliaga, A., Valenzuela-Ríos, J.I., Plasencia, P., Ros, S. (2004): Los fósiles del Muschelkalk (Triásico Medio) en el sector oriental de la Península Ibérica. In: E. Baquedano, S. Rubio (eds.), Miscelania en homenaje a Emiliano Aguirre. II: Paleontología. Museo Arqueologico Regional de Alcalá de Henares: 276-291.

Meyer, H. von (1849): Fossile Fische aus dem Muschelkalk von Jena, Querfurt und Esperstädt. Palaeontographica 1, 195-208.

Muñoz-Chápuli, R. (1985): Sobre la clasificación tipológica del esqueleto dérmico de escualos. Miscelánea Zoológica 9, 396-400.

Pla, C., Marquéz-Aliaga, A., Botella, H. (2013): The chondrichthyan fauna from the Middle Triassic (Ladinian) of the Iberian Range (Spain). Journal of Vertebrate Paleontology 33, 770-785.

Pla, C., Plasencia, P., and Botella, H. (2009): Estudio preliminar de los condríctios del Ladiniense (Triásico Medio) de la sección de Bugarra (Valencia, España). Paleolusitana 1, 383-389.

Raschi, W., Musick, J. (1986): Hydrodynamic aspects of shark scales. NASA Contractor Report 3963: 123 p.

Reif, W. E. (1973): Ontogenese des Hautskelettes von Heterodontus falcifer (Selachii) aus dem Untertithon. Stuttgarter Beitragezur Naturkunde 7, 1-16.

Reif, W. E. (1974): Morphogenese und Musterbildung des Hautzähnchen-Skelettes von Heterodontus. Lethaia 7, 25-42. doi:10.1111/j.1502-3931.1974.tb00882.x

Reif, W. E. (1978): Types of morphogenesis of the dermal skeleton in fossil sharks. Paläontologische Zeitschrift 52, 235-257. doi:10.1007/ BF03006733
Reif, W. E. (1982): Morphogenesis and function of the squamation in sharks. Neues Jahrbuch für Geologie und Paläontologie, Abhandlungen 164, 172-183.

Reif, W. E. (1985a): Squamation and Ecology of Sharks. Courier Forschungsinstitut Senckenberg 78, 1-255.

Reif, W. E. (1985b): Function of scales and photophores in mesopelagic luminescent sharks. Acta Zoologica 66, 111-118. doi:10.1111/j.1463-6395.1985.tb00829.x

Reif, W. E., Dinkelacker, A. (1982): Hydrodynamics of the squamation in fast swimming sharks. Neues Jahrbuch für Geologie und Paläontologie, Abhandlungen 164, 184-187.

Rieppel, O. (1981): The Hybodont sharks from the Middle Triassic of Monte San Giorgio, Switzerland. Neues Jahrbuch für Geologie und Paläontologie, Abhandlungen 161, 324-353.

Scheinpflug, R. (1984): Wirbeltierfunde im mainfränkischen Hauptmuschelkalk. Aufschluss 35, 21-36.

Soto, J., Mincarone, M. (2001): First record of kitefinshark, Dalatias licha (Bonnaterre, 1788) (Chondricthyes, Dalatiidae), in the south Atlantic. Mare Magnum 1, 26-26.

Southall, E.J, Sims, D.W. (2003): Shark skin: a function of feeding. Proceedings of the Royal Society of London B (Suppl.) 270, S47-S49. doi: 10.1098/rsbl.2003.0006 1471-2954

Thies, D., Leidner, A. (2011): Sharks and guitarfishes (Elasmobranchii) from the Late Jurassic of Europe. Palaeodiversity 4, 63-184.

Vickers-Rich, P., Rich, T.-H., Rieppel, O., Thulbom, R. A., McClure, H. A. (1999): A Middle Triassic Vertebrata Fauna from the Jilh Formation, Saudi Arabia. Neues Jahrbuch für Geologie und Paläontologie, Abhandlungen 213(2), 201-232.

\section{APPENDIX}

Percentages of original and cross-validated grouped cases correctly classified obtained using Fourier analysis (Polar and elliptical) with different number of harmonics (20, 40, 60 and 100).

\begin{tabular}{ccccc}
\multicolumn{5}{c}{ Original cases } \\
Number of harmonics & 20 & 40 & 60 & 100 \\
\hline Polar Fourier Analysis & $82 \%$ & $88 \%$ & $88 \%$ & $87 \%$ \\
Elliptical Fourier Analysis & $80 \%$ & $88 \%$ & $86 \%$ & $53,3 \%$ \\
\hline
\end{tabular}

Cross-validated cases

\begin{tabular}{ccccc} 
Number of harmonics & 20 & 40 & 60 & 100 \\
\hline Polar Fourier Analysis & $76 \%$ & $70 \%$ & $72 \%$ & $80 \%$ \\
Elliptical Fourier Analysis & $64 \%$ & $68 \%$ & $66 \%$ & $42,2 \%$ \\
\hline
\end{tabular}

